\title{
ИНТЕРДИСКУРЗИВНИТЕ ПЕРФОРМАНСИ НА КНИЖЕВНОСТА
}

\author{
Марија Горѓиева Димова \\ Универзитет „Св. Кирил и Методиј“, Скопје \\ marija.gorgieva@gmail.com
}

Текстот елаборира една варијанта на пресекот помеѓу интердискурзивните интерференции во книжевноста и интердисциплинарните вкрстувања во книжевната теорија, отелотворен во односот помеѓу наративната фикција и конструктивизмот, којшто интегрира две рамништа на афирмација: рамништето на артикулација на конструктивистичките принципи во наративните текстови и рамништето на толкување на тие текстови низ призма на конструктивистичките концепции. Елаборацијата на поимот конструктивизам се остварува на две рамништа. Прво, на теориско рамниште, преку прегледот на актуелните теориски концепции коишто дефинираат и опишуваат различни аспекти на конструктивизмот (теориите на Е. Глазерсфелд, Х. Фирстер, 3. Шмит, Р. Бројер, Б. Мекхејл). Второ, на интерпретативно рамниште, преку толкувањето на романот Алексанgар и

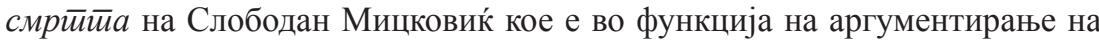
појдовната теза дека историографската метафикција, како парадигматичен постмодернистички жанр, ги демонстрира двете димензии на конструктивизмот: како модус на артикулирање на интердискурзивните релации во романот и како интердисциплинарен херменевтички модел на толкување на романот.

Клучни зборови: конструктивизам, метафикција, историографска метафикција, онтолошка и епистемолошка доминанта 


\title{
INTERDISCURSIVE PERFORMANCES IN LITERATURE
}

\author{
Marija Gjorgjieva Dimova \\ Ss Cyril and Methodius University, Skopje \\ marija.gorgieva@gmail.com
}

The text elaborates on a variation of the intersection between interdisciplinary interferences in literature and interdisciplinary crossings in literary theory, embodied in the relationship between narrative fiction and constructivism, which is propagated on two levels: the level of articulation of constructivist principles in narrative texts and the level of interpretation of those texts through the prism of constructivist conceptions. The elaboration of the concept of constructivism is realized on two levels. First, on a theoretical level, through a review of current theoretical concepts that define and describe various aspects of constructivism (theories of Glasersfeld, Foerster, Schmidt, Breuer, McHale). Secondly, on an interpretive level, through the interpretation of the novel Alexander and Death by Slobodan Micković, which serves as a vehicle for argumenting the starting thesis that historiographic metafiction, as a paradigmatic postmodernist genre, demonstrates both dimensions of constructivism: as a mode of articulation of interdisciplinary relations in the novel and as an interdisciplinary hermeneutic model for interpretation of the novel.

Key words: constructivism, metafiction, historiographic metafiction, ontological and epistemological dominant 


\section{1 Појдовни премиси}

Интердискурзивните и интердисциплинарните испреплетувања, демонстрирани во книжевноста и во книжевната наука, имаат свој континуитет којшто се интензивира во последните децении од XX век, а градира во XXI век. Паралелизмот помеѓу интердискурзивните микстури (особено евидентни во постмодернистичката проза) и интердисциплинарните интерсекции (афирмирани во книжевно-научните дисциплини) се актуализира низ хетероген спектар од варијации и, дополнително, го потврдува реципрочниот, комплементарниот и заемно стимулативниот однос помеѓу книжевноста и нејзиниот метајазик. Овој текст елаборира една точка на пресек помеѓу интердисциплинарните и интердискурзивните тенденции во теоријата и во книжевноста, отелотворен во рамки на конструктивизмот ${ }^{1}$ чиишто теориски премиси, од една страна, се наративно артикулирани во постмодернистичкиот роман и, од друга страна, се втемелени во функционални теориско-херменевтички модели на толкување на книжевните текстови. Следствено, односот помеѓу наративната фикција и конструктивизмот го афирмира интердисциплинарниот пристап кон книжевноста, кој ги интегрира конструктивистичките сознанија не само од книжевната наука туку и од историографијата, од филозофијата и од социологијата на знаењето.

\section{2 Теориски контекстуализации}

\section{1 Конструктивизмот како интердисциплинарен теориски модел}

Промислувањето на односот меѓу наративната фикција и конструктивизмот го претпоставува познавањето на базичните конструктивистички концепти и, следствено, идентификувањето на начините на нивното афирмирање во конкретните книжевни текстови. Потпирајќк се врз емпириските истражувања во невропсихологијата, во когнитивната психологија и во биологијата, односно врз епистемолошките теории на Џ. Б. Вико, И. Кант, Д. Хјум, Л. Витгенштајн и Ж. Пијаже, конструктивизмот се постулира

\footnotetext{
Терминот има и претходни употреби, но со различно значење: и во традиционалната филозофија и во уметноста каде што означува краткотрајно движење (главно во архитектурата) во СССР, во 20-тите години од ХХ век.
} 
како епистемолошка теорија која заговара промени во сфаќањето на поимот стварност и во сфаќањето на односот знаење-стварност. Имено, конструктивистичката парадигма ја проблематизира позитивистичката концепција на стварноста која во конструктивистичката епистемологија е третирана како човечки конструкт, а не како априори даденост. Притоа, не се работи ниту за концептуално негирање на стварноста, ниту за негирање на нејзиното емпириско постоење, туку се проблематизираат начините на достапност на стварноста и можностите за нејзино непроблематично спознавање и прикажување. Следствено, конструктивистичките реконцептуализации на поимот стварност ја заговараат тезата за конструирањето модели на стварност, онака како што таа е искусена. „Стварноста, онака како што ја разбираме, претставува наша инвенција“" (Foerster 1984: 42). „Репрезентациите не се или не може да бидат слики, реплики, копии на еден свет кој е независен од оној кој го искусува“ (Glasersfeld 1989: 437). Овие тези го аргументираат и конструктивистичкиот фокус врз когнитивните процеси, односно врз описите на когнитивниот свет на искуството, наместо и наспроти интересот за онтолошката природа на стварноста. Аналогно на тоа, конструктивистите ја земаат предвид средишната позиција на субјектот - посматрач во когнитивните процеси. „Сѐ е сфатено од страна на еден посматрач и сѐ што е кажано е кажано од страна на еден посматрач на друг посматрач“ (Schmidt 1989: 320). Посредуваниот пристап кон стварноста низ процесите на перцепција и на когниција, кои учествуваат во конструирањето модели на свет, го подразбира субјектот кој не стекнува знаење за „објективните“ одлики на светот (т.е. за она што лежи надвор од неговиот субјективен когнитивен домен) туку субјектот кој проектира сопствена конструкција на стварноста: конструкција која соодветствува на перципираните податоци, којашто зависи од субјектот и којашто се афирмира преку неговите вербални конструкти, бидејќи „разбирањето е чин на интерпретативната конструкција понудена од страна на субјектот“ (Glasersfeld 1989: 437).

Конструктивистичките реконцептуализации на стварноста го имплицираат и редефинирањето на односот знаење - стварност, кое ги фокусира не само начините на стекнување знаење за стварноста туку и неговата доверливост. Оваа релацијаја елаборира Ернст фон Глазерсфелд, промоторот на радикалниот конструктивизам. Тој ја поставува радикалноста во однос на традиционалните концепции за постоење „иконичка кореспонденција меѓу знаењето и стварноста“, наспроти што тој однос е виден како „функционална адаптација“. Епистемолошките импликации на овие редефиниции го постулираат знаењето низ два параметра: 
1. Знаењето како конструкција: бидејќи знаењето не претставува „рефлексија на една 'објективна' онтолошка стварност“, туку „организација на светот конструиран врз основа на нашето сопствено искуство“" (Glasersfeld 1984: 24).

2. Знаењето како интерпретација: бидејќи комуникацијата и разбирањето се резултат на интерпретативната конструкција од страна на субјектот кој искусува. Следствено, знаењето не може да се проценува како вистинито, во смисла на негова кореспонденција со онтолошката стварност (дотолку повеќе што не постои начин да се верификува таа врска), па единствениот критериум за вреднување на знаењето е неговата функционалност и применливост во различни контексти, а како основа за стекнување нови искуства и знаења.

Нашето знаење е корисно, релевантно, ако може да се фати во костец со искуството и ако придонесува за појавата или за избегнувањето на одредени феномени (т.е. настани, искуства). Ако знаењето не служи на таа цел, тогаш тоа се доведува во прашање, станува недоверливо и бескорисно. (Glasersfeld 1984: 23-24)

Премисата на конструктивистичката епистемологија дека сето знаење е конструирано е појдовна точка и во редефинирањето на вистината. Новата епистемолошка парадигма, наместо објективноста (сфатена како упатеност кон еден онтолошки реален свет) и вистината (сфатена како кореспонденција со тој свет), ја афирмира улогата на интерсубјективноста на искуството и на изведливоста и целисходноста на одделните конструкти, во смисла тие да бидат изведени во согласност со одредена намера и да бидат во функција на реализирањето одредена цел.

Конструктивизмот поаѓа од претпоставката дека сета когнитивна активност се случува во искуствениот свет на свеста, која е насочена кон одредена цел. Таквата насоченост нема ништо заедничко со целите во 'надворешната стварност'. (Glasersfeld 1984: 32)

\section{2 (Мета)фикциските перформации на конструктивизмот}

Афирмацијата на комплексот конструктивистички премиси е евидентна и во наративните текстови, и во нивните толкувања па и, пошироко, во проучувањето на системот на книжевноста. Интересот за 
конструктивистичките артикулации во фикциските текстови е аргументиран со фактот што токму наративната проза нуди бројни можности за конструирање алтернативни модели на стварност. ${ }^{2}$

Книжевноста е единственото место каде што конструкцијата на моделите на свет како такви станува тематска и каде што таа тематизација може да ги заземе сите позиции од ортогоналните модели до оддалечените светови на имагинацијата. (Schmidt 1984: 265)

Низ призма на конструктивистичките концепции, толкувањето на наративните текстови се фокусира врз начините на коишто тие, експлицитно или имплицитно, ги артикулираат конструктивистичките теми: од една страна, темата за конструираната природа на стварноста, на минатото, на вистината и на идентитетот; од друга страна, темата за субјективната обележаност на перцепцијата, на знаењето и на значењето. „Системот на книжевноста, се чини, максимално е отворен кон сите постапки кои когнитивно се реализираат како конструкции на значењето низ јазикот“ (Schmidt 1984: 267). Вообичаено, наративните/романескните текстови (за разлика од драмската фикција) се најподатливи за афирмација на теориските премиси на конструктивизмот, токму поради присуството на нараторот како организирачка свест на текстот која учествува во интерполирањето на рефлексивните структури. Книжевната практика осведочува два модуса на наративна конверзија на конструктивистичките принципи:

1. Играта со гледните точки како наративна постапка која на структурно рамниште ги илустрира проблематизациите на стварноста: сугерирајќи ја нејзината зависност од перцепцијата и нејзината посредувана достапност и, индиректно, оспорувајќи го нејзиниот статус на „објективна“ стварност.

а. Мултифокализацијата, која оперира со сопоставувањето на неколку перспективи, ги нагласува релативитетот и конструираната природа на фикцискиот свет, односно на искуството на ликот.

б. Рестриктивните перспективи кои ефектуираат со нагласување на субјективната обележаност на когницијата и на искуството.

2. Метафикциските постапки, како механизам на наративно конвертирање на конструктивистичките принципи, нудат широк спектар на тематизирање на „конструктивитетот и на субјективната детерми-

\footnotetext{
2 Да потсетиме на теоријата на Јуриј Лотман за книжевноста како секундарен моделативен систем, којшто ги создава книжевните модели како аналогони на стварноста и чијашто моделативност има спознајна функција (1970: 61-81).
} 
нираност на когницијата“" (Nünning 1989: 7), како и нивна афирмација на ниво на експлицитни коментари од страна на ликот или на нараторот.

Конструктивистичките артикулации во рамки на саморефлексивноста се појдовна точка и во истражувањето на Ролф Бројер: според него, метакнижевноста коинцидира со конструктивистичките концепции, бидејќи таа го свртува вниманието врз сопствениот статус на артифициелен конструкт, оголувајќк ги процесите на сопствената конструкција. Автореференцијалниот фокус на текстот, за сметка на референцијалната упатеност кон стварноста и кон начините на нејзина репрезентација, Бројер го објаснува со два факта. Од една страна, со проблематизирањето на традиционалните концепции на односот фикција - стварност, што се манифестира низ сомнежот во постоењето кохерентна стварност и во можностите за нејзина непроблематична репрезентација.

Фикциските текстови се занимаваат со 'конструкции', а не со фактуални дескрипции или со текстови кои се однесуваат на стварноста која е надвор од нив, така што 'структурата' е важна исто колку и стварноста што се чини дека ја опишуваат. (Breuer 1984: 162)

Од друга страна, со мноштвото иманентни проблематизации на инхерентните одлики на книжевниот систем: проблематизациите на јазичниот медиум, на постојните книжевни форми, на постапките на репрезентација, на односот кон читателот:

Авторот на фикциските текстови може да пишува единствено за пишувањето или, попрецизно, може да пишува само за неможноста на пишувањето, парадоксално, надевајќи се да ја продолжи својата професија. (ibid, 166)

Промислувањето на метафикцијата низ призма на конструктивистичките премиси е сугерирано и во дел од тезите на Патриша Во (иако таа не го употребува поимот конструктивизам). ${ }^{3}$ Комплексната дефиниција на метафикцијата како „фикциско пишување кое е самосвесно, кое системски го свртува вниманието врз својот статус на артефакт со цел да го проблематизира односот фикција - стварност“ (Waugh 1996: 2), недвосмислено, го афирмира метафикциското поимање на стварноста како конструкт кој е истражуван низ текстуалната самореференција.

3 Патриша Во, како и најголем дел од книжевните теоретичари, главно, реферираат на конструктивистичката парадигма на Питер Бергер и Томас Лакман која се фокусира врз социјалната конструкција на реалноста. 
Ако конструктивизмот подразбира компетитивен и проблематизирачки однос кон реализмот, тогаш метафикциското упатување на стварноста во категориите на текстуалноста, ги проблематизира премисите на книжевниот реализам: оголувајќи ги претпоставките врз коишто се темели реалистичкиот роман, метафикцијата ќе покаже дека јазикот на реализмот не репродуцира објективно дадена стварност туку самиот конструира верзија на стварноста. Според тоа, метафикцијата не воспоставува опозиција спрема „објективните факти“ од емпирискиот свет, туку спрема јазикот на реалистичката проза и нејзините конвенции кои ја поддржуваат здраворазумската претстава за стварноста. Во таа смисла треба да се сфати и метафикциската проблематизација на поимот стварност. Прво, покажувајќи дека секоја претстава за стварноста и секое нејзино толкување се условни конструкции, на преден план се поставува прашањето за природата на процесите на врамување со коишто се обликуваат тие конструкции. Второ, потврдувајќи дека нашите претстави за стварноста не се едноставно дадени туку се јазично конструирани, на преден план ги поставуваме јазично обликуваните светови и јазично посредуваните знаења за светот. Метафикцијата ја истражува фикционалноста низ опозицијата меѓу конструирањето и кршењето на илузијата, низ „симултаното креирање на фикцијата и правењето исказ за таа креација““(Waugh 1996: 97). Оголувајќи ги постапките кои учествуваат во креирањето илузија за стварноста, целта на метафикцијата е да го истакне релативитетот на световите и на вистините кои се конструирани во фикциските текстови. Значи, метафикциските текстови, посматрани како носители на конструктивистичките рефлексии, го артикулираат поимањето на стварноста како (фикциски) конструкт.

\section{3 Конструктивизмот како теориско - херменевтички модел}

Со оглед на тоа што (мета)фикциските текстови артикулираат дел од конструктивистичките премиси, повратно, и самите тие стануваат податливи за толкување низ призма на конструктивистичките теориски модели. „Нема причина зошто лингвистичките или стилистичките стратегии на конструкција на стварноста во 'фикцијата' би се разликувале од стратегиите на конструкција на стварноста во 'не -фикцијата'“ (Schmidt 1984: 266). Таквото толкување ги фокусира формалните рамништа на текстот (кои ја манифестираат субјективноста, релативноста, конструктивитетот на искуството и на знаењето), текстуално афирмираните когнитивни процеси, тематските и структурните одлики на текстот што ги актуализираат и пошироките епистемолошки прашања и теми. 
Консеквенциите на конструктивистичката епистемологија во однос на книжевните проучувања и толкувања се елаборирани и од страна на Брајан Мекхејл. Основниот епистемолошки принцип од којшто поаѓа тој се однесува на теориската зависност на сите когнитивни операции, вклучително и на перцепцијата.

Податоците не постојат независно од теоријата што ги конституира како податоци; тие не се толку 'дадени' колку што се 'направени': податокот е податок во светлина на теориската рамка на поединечниот набљудувач (McHale 2002: 2).

Конструктивистичките опсервации на Мекхејл во книжевно-теориски и во книжевно-историски контекст нудат неколку битни импликации. Прво, ја посочуваат перспективистичката втемеленост на конструкциите: тие се видени како потенцијално прифатливи верзии на книжевно-историските „објекти“ кои се актуализираат како предмет на интерес во одреден теориско-истражувачки контекст, така што плуралитетот конструкции ги поставува продуктивноста и стратешката употребливост на конструкциите како критериуми за нивни избор. Мекхејл пронаоѓа една конкретизација на конструктивистичките опсервации на книжевно-историските „објекти“ на рамништето на коешто се конструираат книжевните истории, одредница со којашто се надминува тезата за постоењето единствена, сеопфатна книжевна историја. Конструктивистичкиот пристап во книжевноисториските проучувања е фокусиран врз „проблемот на йоврзувањеӣо на податоците во пошироки единици како, на пример, 'периоди', 'школи', 'жанрови' кои, исто така, се само конструкти“ (ibid, 2). Во тој контекст, и постмодернизмот (подеднакво, како и ренесансата, или, пак, романтизмот) функционира како еден книжевно-историски „објект“-конструкт: од една страна, бројните теориски конструкции кои го деривираат постмодернизмот (на пример, на Линда Хачон, на Жан Франсоа Лиотар, на Брајан Мекхејл) и кои, посредно, го заговараат неговиот дискурзивен и конструиран карактер; од друга страна, мноштвото дискурзивни конструкции што ги создава самиот постмодернизам. ${ }^{4}$ Второ, ако книжевно-историските „објекти“ се конструирани, а не априори дадени или „откриени“ категории, тогаш се актуализира и прашањето за начините на нивно конструирање,

\footnotetext{
${ }^{4}$ Конструктивизмот е поставен и во каталогот својства на постмодернизмот, сочинет од Ихаб Хасан. Тој говори за сеприсутноста на конструктивистичките претпоставки преку коишто постмодернизмот го поддржува „движењето од единствената вистина и востановениот и втемелен свет кон разновидноста на сопоставените верзии на светови во создавање“. Спектарот конструктивистички манифестации, од една страна, се врзува за постмодернизмот кој ја „конструира“ стварноста со „фикции“, а од друга страна, со актуелните тенденции во херменевтичката и во постструктуралистичката теорија (Hassan 1987: 29-30).
} 
т.е. за дискурзивниот облик во којшто се изведува конструкцијата. Во современ контекст, евидентна е актуелноста на наративните конструкции, што конвенира и со тезите на конструктивистичката историографија за доминантните наративни модуси на конструирање на историјата, вклучително и на книжевните истории.

Зигфрид Шмит ја заговара емпириската концепција на книжевните студии во рамки на конструктивистичката теорија на когниција, којашто ќе обезбеди основа за сите активности во книжевната комуникација, вклучувајќи ги главните епистемолошки, методолошки, етички и апликативни аспекти на новиот пристап кон книжевноста, видена како социјален систем. Конкретно, за Шмит, системот на книжевноста претставува подрачје на социјална акција каде што постојано се манифестираат конструктивитетот на искуството и на знаењето (1984: 264; 1989: 319323). Можните модели на конструктивистичко читање на наративните текстови се понудени во интерпретацииите на Ернст фон Глазерсфелд, на Барбара Ромерскирхен и на Ансгар Нининг кои, главно, се фокусирани врз романите на Џон Фаулс. ${ }^{5}$ Зигфрид Шмит го толкува солилоквијот на Моли Блум во последната глава на Улис (сочинет од околу 40.000 зборови) како ремек-дело на конструктивистичката книжевност. Ролф Бројер, пак, ја елаборира врската на романот со конструктивизмот во трилогијата на Семјуел Бекет: Molloy, Malone Dies, The Unnaimable, со цел да докаже дека модернистичката проза е „вистинскиот дом на саморефлексивноста“. Во рамки на постмодернистичката книжевност, историографската метафикција претставува парадигматична жанровска илустрација на конструктивистичките рефлексии во фикцијата. Оваа парадигматичност има тројна аргументација:

1. Историографската метафикција, низ призма на својата онтолошка доминанта (афирмирана низ проблематизацијата на границите помеѓу световите/текстовите) и низ призма на епистемолошките тематизации (афирмирани низ сомневањето во можноста за стекнување непроблематичен пристап кон историската стварност и стекнување знаење за неа) афирмира дел од постмодернистичките проблематизации на историјата и на фикцијата, односно на нивниот меѓусебен однос низ призма на конструктивистичките идеи: романите ја афирмираат „теориската самосвест за историјата и за фикцијата

5 Според Глазерсфелд, Волшебникой на Фаулс е „еден од малубројните книжевни дела во кое без особен напор можам да го читам погледот на свет на конструктивистичката теорија на знаењето“ (179:444). Според Барбара Ромерскирхен овој роман на Фаулс е „парадигматичен конструктивистички роман“ (1999: 19). 
како човечки конструкти“ (Hutcheon 1988: 20), илустрирајќи ги процесите на нивно конституирање како објекти на нашето разбирање и толкување.

2. Историографската метафикција ги употребува метафикциските постапки во насока на проблематизирање на постоењето кохерентна стварност, паралелно, проблематизирајќи ги и постапките на репрезентација на стварноста во реалистичкиот роман. Во тој контекст, романите ги артикулираат и конструктивистичките сфаќања на стварноста и епистемолошките аспекти на односот знаење стварност. „Историографската метафикција ги актуализираше конструктивните постапки на реплицирање на официјалните историографски оптики, за претворање на романот/фикцијата во псевдоисториски, ревизионистички конструкт“"(Кулавкова 2009:157).

3. Историографската метафикција како вид теориска фикција (Currie 1998) ги перформира во наративен контекст и одделните теориски концепции на конструктивизмот (првенствено, оние во историографијата, застапувани од страна на Леон Голдштајн и на Франк Анкерсмит, но и оние во книжевната теорија - Патриша Во, Брајан Мекхејл, Елизабет Веселинг, Ансгар Нининг).

Конструктивистичките концептуализации на когницијата, на историографијата и на книжевната теорија обезбедуваат херменевтичка рамка во којашто ќе се ситуираат и конструктивистичките читања на историографските метафикции. Овој херменевтички модел е оправдан и функционален, ако се земе предвид дека се работи за романи кои го актуализираат и прашањето за онтолошкиот статус на историската стварност, како и прашањето за епистемолошките и за методолошките проблеми на историографијата, паралелно, развивајќи висок степен на метафикционалност.

\section{3 Интерпретативни контекстуализации}

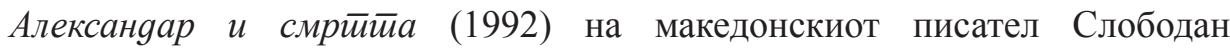
Мицковиќ (1935-2002) е извонредно парадигматичен роман од аспект на демонстрирањето на наративната конверзија на конструктивистичките концепти во книжевната практика, што се евидентира на три рамништа: наративно, метафикциско и епистемолошко. 


\section{Нарайивно рамнишйе}

Романот го допушта интерпретативниот фокус врз оние негови тематски и структурни одлики кои се потпираат врз пошироките онтолошки, епистемолошки и метаисториографски прашања, а коишто ги истражуваат релациите меѓу наративните структури и нивните епистемолошки импликации и коишто ги истакнуваат субјективитетот, релативноста и конструктивитетот на знаењето.

Преку формалната анализа на наративната фикција, конструктивистичката критика го истражува прашањето за тоа чии искази за природата на стварноста и на историјата престојуваат во структурата на книжевните текстови. (Schmidt 1989: 322)

Во романот на Мицковиќ носител на тие искази е ликот-наратор, Архидеј Потивов, кој, од позиција на учесник/посматрач, наративно ја конструира и ја осмислува стварноста - актуелна и мината. Имено, тој говори за императорот Александар Велики и врз основа на своето искуство со него (во минатото, како негов оружар) и врз основа на непосредната перцепција на актуелните погребни активности. Фокусирајќи се врз начинот на кој ликот ја конструира стварноста, романот ги користи соодветните наративни постапки како книжевни артикулации на конструктивистичките теми. Прво, раскажувањето во прво лице кое ја потенцира субјективноста на когницијата, на искуството и на знаењето, нагласувајќи го конструираниот идентитет на покојниот император. На тоа рамниште, повеќекратно, се потенцираат дискрепанциите меѓу „официјалната“ историја за императорот и верзиите кои се конструирани од страна на Архидеј: неговите дневничкоепистоларно-мемоарски записи го сугерираат расчекорот меѓу историските настани и нивните репрезентации. Иако Архидеј е учесник во настаните за коишто известува, сепак, начинот на воспоставување на врската меѓу настаните и нивната наративна репрезентација упатува на заклучокот кој е сугериран и во конструктивистичките концепции: сведокот може да обезбеди само фрагментарен опис, полн со предрасуди и со селективни рестрикции. Оттаму, романот го свртува вниманието врз неизбежните посредувачки облици на достапност на минатото - врз наративно приопштените искуства и сеќавања, продуцирани од страна на оние кои биле вовлечени во настаните и кои ги интерпретираат од својата гледна точка. Значи, конструктивистичките рефлексии во романот се во директна спрега со наративните техники кои ја тематизираат процесуалноста на (за) пишувањето и на фабрикувањето актуелни репрезентации на историјата. Во поширока, конструктивистичка смисла, романот го илустрира непостоењето 
„иконичка кореспонденција меѓу перцепцијата и субјективното искуство и стварноста“"(Glasersfeld 1984: 24), имплицирајќи дека и знаењето се заснова на интерпретација и, следствено, тоа не може да биде ниту објективно, ниту доверливо. Второ, романот ја користи рестриктивната гледна точка како постапка која го мотивира оградувањето на сведокот од она што се наоѓа надвор од неговата перцепција, надвор од неговото искуство и од неговото сеќавање.

Токму како што и јас сум негов промашен толкувач, поранешен а некогашен

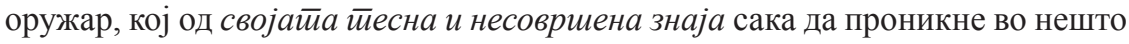
што далеку го надминува. Учителу, разбери го и мојот пелтечав напор нешто да ти објаснам и да ти откријам. Ти ќе го препознаеш и ќе го отфрлиш она итио ӣроизлегуува оg самољубиет̄о кое секог̄аш несреќно се вкрсӣува со незнаењейо. (Мицковиќ 1992:39) [нагласок додаден од авторката]

Овие наративни постапки се повеќекратно индикативни. Прво, тие го илустрираат преместувањето на фокусот од историските настани/фигури кон субјективните искуства и перцепции на поединецот, така што романот на преден план ги поставува процесите на конструкција на искуството и конструираната природа на историската стварност. Второ, во поширока

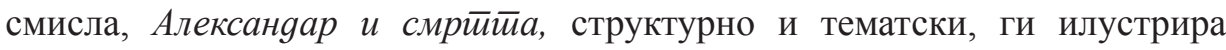
интервенциите на субјективитетот во однос на стварноста (врз што се темели секој пристап кон историјата) и, на тој начин, актуализира дел од премисите на конструктивистичката историографија: историографијата, многу повеќе, е начин на упатеност во минатото, одошто содржина на знаењето, па фокусот е поставен врз активниот однос кон историјата, односно врз „процедурите на конструирање на историското минато“(Goldstein 1977: 35). Катица К'улавкова, во анализата на интертекстуалните релации и постапки во романот на Мицковиќ, ги евидентира и неговите отстапки во однос на конвенциите на историскиот роман: главно, тој ревизионситички однос е сигнализиран преку ревидирање на референцијално-миметичкиот однос кон историската стварност. „Односот историска предлошка и романескна визија не е спознајно-прикажувачки, не е насочен директно спрема референтот - стварноста и нејзиниот прототип, туку е свртен кон самиот романескен предмет кој е во формирање, кој води дијалог со историскиот материјал“ (Ку улавкова 1996: 234).

\section{Мейафикциско рамнишйе}

Дел од конструктивистичките принципи во романот се манифестираат и низ комплексот метафикциски постапки и коментари коишто ја тематизи- 
раат и структурно ја демонстрираат процесуалноста на запишувањето и на конструирањето актуелни репрезентации на историјата. Метафикционалноста, како експонент на конструктивистичките рефлексии, главно, оперира на автореференцијално рамниште: како свест за сопствените процеси на конструирање и на селектирање врз коишто се потпира интересот за историјата, при што тие процеси секогаш се прикажани како историски одредени чинови. Варијантите на автореференцијално и на интертекстуално проблематизирање на конвенциите на историографијата и структурното истакнување на субјективитетот и на конструктивитетот, подеднакво, го афирмираат конструктивистичкиот поглед врз минатото: и автореференцијалните и интертекстуалните постапки ги сигнализираат префокусирањата (констатирани и во историографијата) од „историјата како серија минати настани“ кон „историјата како активност на историчарот“ (Ankersmit 1994: 176).

\section{Ейисйемолочко рамнишйе}

Конструктивистичките концепти во романот се артикулираат и низ епистемолошките тематизации, конкретизирани во проблематизацијата на односот знаење - стварност. Повеќекратното демонстрирање на перспективистичката природа на знаењето на Архидеј има неколку епистемолошки импликации: поткопување на илузијата за апсолутно знаење, проблематизација на процесите на трансмисија на знаењето за минатото и афирмација на односот кон историјата како процес на интерпретација и на конструкција. Романот го илустрира, односно нараторот го искусува начинот на којшто процесот на константни (ре)интерпретации на историските настани/фигури ја потенцира епистемолошката несигурност во однос на спознавањето на стварноста. Толкувачката призма, која го посматра романот како израз на наративните артикулации на конструктивизмот, станува оправдана и со оглед на неговите метаисториографски импликации: критичките коментари на историографијата, афирмирани во романескното проблематизирање на природата и функцијата на историското знаење. Во прилог на тоа оди и романескната проблематизација на монолитната, апсолутната и конечната вистина за минатото, а во корист на тезата за постоењето единствено серија верзии и вистини (во плурал) кои зависат од учесникот/сведокот и кои се конструирани од него. Вистините кои ги конструира Архидеј се функционално создадени конструкти во двојна насока: прво, тие се во функција на демистифицирање на божественото потекло на императорот и на демитологизирање на неговата личност низ откривањето на човечките слабости на Александар; второ, тие се во функција на конструирање 
на вистината од позицијата на ексцентрираните - на заборавените, на неуспешните, на социјално мајоризираните, на маргинализираните, на стигматизираните, на жртвите (позиција која ја застапува оружарот, со оглед на неговата маргинализираност во државничката и во социјалната хиерархија на империјата). Оттаму, неговото сведоштво е целисходен и функционално сочинет конструкт: тоа е облик на (суб)верзија на доминантните перспективи и на официјалните верзии, односно облик на персонална интерпретација и ревизија на историското минато врз основа на сопственото искуство. „Сето тоа го пишував зашто мене ме засегало, зашто јас сум бил присутен, јас тоа сум го доживувал, тоа на мене се однесувало“ (Мицковиќ 1992: 267). Оголувајќи ги процедурите на ретроактивно и ретроспективно осмислување на минатото од страна на ликот-наратор, романот го нагласува и конструираниот карактер на значењето, аргументирајќи дека значењето не се содржи во настаните, туку во системите кои ги претвораат тие настани во актуелни историски факти: настаните стануваат разбирливи и осмислени кога ќе бидат наративизирани, кога ќе се вклучат во рамката на една приказна и ќе добијат определено значење. Ако „наративизацијата на стварноста значи наметнување врз таа стварност форма на приказна“ (White 1990: 2), тогаш процесот на наративизација на реалните настани, всушност, е и процес на трансформација на настаните низ формалните барања на наративот. Наративизацијата на персоналното/историското минато што ја спроведува Архидеј, од една страна, го демонстрира чинот на селективно-интерпретативното изведување на фактите наспроти настаните и, од друга страна, ја потврдува автономијата на наративните конвенции со свест за нивната обликувачка интервенција врз историската стварност, која наративно се приопштува. Следствено, личното и историското знаење се понудени како можна перспектива, а историскиот факт како дискурзивна конструкција. Проблематизацијата на селектираните, конструираните факти во однос на минатите настани го генерира историското знаење како условно, привремено, релационо и контекстуално, односно како резултат на постапките на конструкција и на (ре)интерпретација на субјектот кој

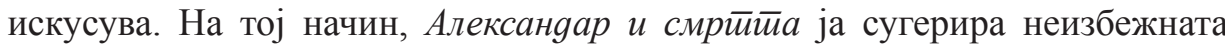
субјективност која лежи зад процесите на селекција, на интеграција и на интерпретација на фактите ${ }^{6}$ и, посредно, ја афирмира таа субјективност како проблематизација на претензиите кон историската вистина. Форматот на (за)пишано сведоштво ја сугерира дискрепанцата меѓу минатото

6 Глазерсфелд се повикува на етимологијата на поимот факт (facere, да се прави), што имплицира дека субјектот го знае само она што го направил, што го конструирал како факт, направен од елементи кои му се достапни на оној кој ги прави (1989: 438). Овие аспекти во историографски контекст ги потенцира Хејден Вајт според кого историчарот „ги моделира фрагментите на минатото во целина чијшто интегритет е чисто дискурзивен“" (White 1986: 125). 
и запаметената верзија за минатото, меѓу стварноста и субјективните искуства, меѓу настаните и нивните запишани репрезентации, притоа давајќи приоритет на втората позиција во парот. Интериоризираната тематизација на односот помеѓу предлошкото и дневничкото известување, помеѓу сведоштвото и ретроспективните и дистанцираните коментари кои, подеднакво, се однесуваат и на осведоченото (настаните) и на запишаното сведоштво, практично, ја посредува и проблематизацијата на односот меѓу двете рамништа на кои реферира амбивалентниот поим историја: рамништето на настаните (res gestae) и рамништето на наративните прикази на тие настани (historia rerum gestarum), меѓу „историјата како што е искусена“ и „историјата како запис на нешто што се случило во минатото“ (Ankersmit 1994: 174). Повратно, интерпретативните маневри изведени во просторот меѓу тие две рамништа резултираат со нагласувањето на статусот на историската реалност како конструкт: таа може да се (де)формира, да се (пре)обликува, да се фалсификува, да се (де)мистифицира, односно секогаш одново да се конструира. Впрочем, и нарацијата во прво лице треба да се сфати како постапка со којашто се нагласува субјективноста на когницијата: автореференцијалните коментари упатуваат на интервенциите што произлегуваат од рестриктивната позиционираност на сведокот, но и од субјективната обележаност на неговите толкувања. „Она што го знам ме фрла во тежок очај, а од она што не го знам, што се случува зад мене, или што го гледам а не го виѓавам и не го разбирам, сигурно би паднал во безнадежна неподвижност“ (Мицковиќ 1992, 300).

Врз фонот на конструктивистичките премиси дека моделите на свет се субјективни конструкти коишто го афирмираат „разбирањето како работа на интерпретативните конструкции од страна на субјектот“" (Glazersfeld 1989: 437) треба да се посматра и несигурноста што ја демонстрира Архидеј, оградувајќи се од она што се наоѓа надвор од неговиот перцептивен домен, надвор од неговото искуство и од неговото сеќавање. Затоа, секој негов извештај упатен до Аристотел е мотивиран од потребата „да испишувам сѐ што ми минува низ главата“ (Мицковиќ 1992: 21) и е проследен со прекумерната употреба на јазичните сигнализатори на рестриктивната и, во таа смисла, недоверливата позиција на сведокот („не знам“, „мислам“, „можеби“, „тоа сигурно го знам“, „не знам, не сум сигурен“, „барем колку што јас знам“, „ми се чини“, „се надевам“, „се сеќавам“).

\section{4 Заклучок}

Конструктивизмот, како иманентно интердисциплинарен модел на проучување, е исклучително парадигматичен во насока на илустрирање на 
интердискурзивните и интердисциплинарните преплетувања помеѓу книжевноста и книжевната наука. Елаборацијата на наративните конверзии на конструктивистичките концепти и нивниот трансфер во теорискохерменевтичките промислувања на книжевноста, упатува на два заклучока. Прво, на постоењето иманентна предиспонираност на постмодернистичката проза кон конструктивистичките концепции, со оглед на нејзината обележаност со неколку поетички доминанти: со жанровските хибридизации со интердискурзивен предзнак, со онтолошките и епистемолошките тематизации, со метафикциските наративни постапки. Второ, упатува на комплементарниот, реципрочниот и заемно стимулативниот однос помеѓу книжевноста и теориските модели на нејзино толкување, со оглед на тоа што наративната артикулација на конструктивизмот имплицира и создавање на интердисциплинарни конструктивистички модели на проучување и во книжевно-научен контекст, особено евидентно во теоријата на книжевност, во книжевната историја и во книжевната херменевтика.

\section{Библиографија}

Мицковиќ, С. (1992). Алексанgар и смрӣ̄̄а. Скопје: Култура.

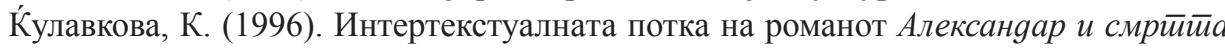
од Слободан Мицковиќ. Во К. К'улавкова (уред.). Пойхоg и ucxog, 231-24. Скопје: Култура.

Куулавкова, К. (2009). Историографската метафикција како метаисториографска фикција: критичко препрочитување на метафикциската парадигма. Во К.

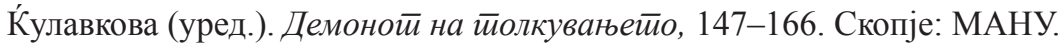

Ќулавкова, К. (2008). Македонската историографска метафикција. Во Зборник og

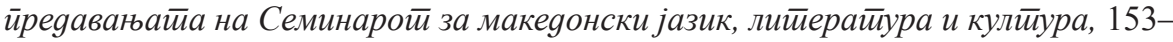
168. Скопје: Универзитет „Св. Кирил и Методиј“.

Ankersmit. F. (1994). History and tropology: The rise and fall of metaphor. Berkely: University of Califormia Press.

Berger, P. L. and Luckmann, T. (eds.) (1989). The social construction of reality. New York: Anchor Book.

Breuer, R. (1984). Self-reflexivity in literature: The example of Samuel Beckett's novel trilogy. In P. Watzlawick (ed.). The invented reality, 145-168. New York/London: W. W. Norton Company.

Currie, M. (1998). Postmodern narrative theory. New York: St. Martin's Press.

Foerster, von H. (1984). On constructing a reality. In P. Watzlawick (ed.). The invented reality, 41-61. New York/London: W. W. Norton Company.

Glasersfeld, von E. (1984). An introduction to radical constructivism. In P. Watzlawick (ed.). The invented reality, 17-40. New York/London: W.W. Norton Company. 
Glasersfeld, von E. (1989). Facts and the Self from a constructivist point of view. Poetics, 18: 435-448.

Goldstein J. L. (1977). History and the primacy of knowing. History and Theory, 4: $29-52$.

Hassan, I. (1987). Pluralizam u postmodernističkoj perspektivi. Quorum 3 (4): 23-41.

Hutcheon, L. (1988). A poetics of postmodernism: History, theory, fiction. New York and London: Routledge.

Lotman, J. M. (1970). Predavanja iz strukturalne poetike. Sarajevo: Zavod za izdavanje udžbenika.

McHale, B. (2002). Constructing postmodernism. London and New York: Routledge.

Nunning, A. (1989). Baustaine einer Konstruktivistischen Erzhältheorie. Die erzählerische Umstetzung Konstruktivistischer Konzepte in den Romanen von John Fowles. Delfin, 13 (3): 3-17.

Rommerskirchen, B. (1999). Constructing reality. Frankfurt am Main: Peter Lang Europäischer Verlag der Wissenschaften.

Schmidt, S. J. (1984). The fiction is that reality exists: A constructivist model of reality, fiction, and literature. Poetics Today, 2: 253-274.

Schmidt, S. J. (1989). On the construction of fiction and the invention of facts. Poetics, 18: 319-335.

Watzlawick, P. (ed.) (1984). The invented reality. New York/London: W. W. Norton Company.

Waugh, P. (1996). Metafiction: The theory and practice of self-conscious fiction. London and New York: Routledge.

White, H. (1986). Tropics of Discourse. Baltimore and London: The John Hopkins University Press.

White, H. (1990). The content of the form. Baltimore and London: The John Hopkins University Press. 